pre-Malays or Caucasian Indonesians, are here intruders. Intruders from where? Obviously from where the type exists, the neighbouring Indo-Chinese peninsula. What then becomes of the Malay as a primary division of mankind? As such it can no longer be recognised in anthropology, and must sink to the position of a mere variety of the Mongol type. The so-called true Malay or typical Malay is essentially a Mongolian, and the likeness between the two has not failed to strike all careful observers. "The Malayan race," says Wallace, "as a whole undoubtedly very closely resembles the East Asian populations from Siam to Manchuria. I was much struck with this, when in the Island of Bali I saw Chinese traders, who had adopted the costume of that country, and who could then hardly be distinguished from Malays; and on the other hand I have seen natives of Java who, as far as physiognomy was concerned, would pass very well for Chinese." Hence De Quatrefages rightly rejects the claim of the Malays to be regarded as a fundamental type. "All polygenists," he remarks, "have regarded the Malays as one of their human species; many monogenists have considered them as one of the principal races. I showed long ago that in reality they are only a mixed race in which white, black, and yellow elements are associated."

The last clause of this sentence gives the true solution of the problem. The inhabitants of Malaysia consist not of one, nor even of three distinct races, but of three races variously intermingled, the yellow or Mongolian, and the white or Caucasian chiefly in the west, these two and the black or Papuan chiefly in the east. As the fusion of yellow, white, and black produces the so-called "Alfuros" in the east, so the fusion of yellow and white produces the so-called Malays in the west. The more the yellow prevails the near $r$ do the Malays approach the Mongol type; the more the white prevails the nearer do they approach the Caucasian type, until in some places they seem to be no longer distinguishable from the Mongols, in others from the Caucasians. The Javanese are taken for Chinese by Wallace, just as the Mentawey Islanders are taken for Sawaiori or Eastern Polynesians by von Rosenberg. Under these circumstances it is not surprising that those who seek for unity in the Archipelago should meet with nothing but confusion. Prof. Flower comments on the divergent characteristics presented by the Malayan crania, remarking that "there is certainly no very great conformity in the characters of the skulls in our collections which are said to belong to Malays." This must always be the case until we come to an understanding as to the meaning of the term Malay, which after all is far more a national and linguistic than a racial expression. Proceeding on the groundless assumption of a common Malay type in Oceanica, Welcker arrived at the subjoined astonishing results from cranial measurements in Micronesia and Malaysia alone :-

\begin{tabular}{|c|c|c|c|c|c|c|c|c|}
\hline \multicolumn{9}{|c|}{ Length of Skull 1oo } \\
\hline \multirow{3}{*}{\multicolumn{3}{|c|}{$\begin{array}{l}\text { Caroline Islanders } \\
\text { "Alfuros" } " \ldots \quad \ldots\end{array}$}} & \multicolumn{3}{|c|}{$\begin{array}{l}\text { Index of } \\
\text { breadth. }\end{array}$} & \multicolumn{2}{|l|}{$\begin{array}{l}\text { Index of } \\
\text { height. }\end{array}$} & Difference \\
\hline & & & $\cdots$ & & $\cdots$ & 74 & $\cdots$ & +6 \\
\hline Dyaks of $B$ & orne & & $\cdots$ & 74 & $\cdots$ & 79 & $\cdots$ & +5 \\
\hline Balinese & $\ldots$ & & $\cdots$ & 75 & $\cdots$ & 77 & $\cdots$ & +2 \\
\hline Amboynese & $\ldots$ & $\begin{array}{l}\cdots \\
\cdots\end{array}$ & $\cdots$ & 76 & $\cdots$ & 77 & $\cdots$ & $+I$ \\
\hline Sumatran & $\ldots$ & $\ldots$ & $\ldots$ & 77 & $\cdots$ & $\begin{array}{l}77 \\
78\end{array}$ & $\cdots$ & $\begin{array}{l}+04 \\
+1\end{array}$ \\
\hline Macassar & $\ldots$ & $\ldots$ & $\cdots$ & 78 & $\begin{array}{l}\cdots \\
\cdots\end{array}$ & 78 & $\begin{array}{l}\cdots \\
\cdots\end{array}$ & $\begin{array}{l}+1 \\
-0.5\end{array}$ \\
\hline Javane & $\cdots$ & $\ldots$ & ... & 79 & $\ldots$ & 80 & $\ldots$ & +0.4 \\
\hline ese & $\cdots$ & $\cdots$ & $\cdots$ & 79 & $\cdots$ & 80 & $\ldots$ & +0.4 \\
\hline Menadorese & $e . .$. & $\cdots$ & $\cdots$ & 80 & $\ldots$ & 81 & $\ldots$ & \\
\hline Madurese & $\ldots$ & $\ldots$ & $\ldots$ & 82 & & 82 & $\ldots$ & -0.1 \\
\hline
\end{tabular}

Yet even here Sumatran is taken as a unit, although it is not hazarding too much to say that a comparison of Atyeh, Batta, Palambang, Janebi, Siak, Menangkabu, Korinchi, Rejang, Lampung, and other crania from that island alone would probably yield almost as many dis. crepancies as are revealed in this table. There is in fact less uniformity of type in Malaysia alone, with a population of some $25,000,000$, than in the whole of China and Mongolia with a probable population of $400,000,000$.

(To be continued.)

A. H. KEANE

\section{A CHAPTER IN THE HISTORY OF THE CONIFERAE}

II.

\section{GrNkgo (Linnæus)}

THE perhaps better known name of this genus is 1 Salisburia (Smith), but the Linnæan name, adapted from the Chinese, has unfortunately priority. The genus contains only one existing species, the gigantic Ginkgo biloba of Northern China and Japan. It is classified with the Taxeæ, is diœcious, and the flabelliform leaves are deciduous, leathery, very variably lobed, and of all sizes up to an extreme of five inches across. The fruit, about an inch in diameter, is drupaceous, on a slender footstalk, composed externally of a fleshy layer, and internally of a hard light-coloured shell, and is somewhat unsymmetrical, owing to the abortion of one of the seeds. The foliage is like that of the maidenhair fern, but the petiole is stout, often three inches long, and distinctly articulated at the base. An important characteristic in recognising the fossil leaf, besides the petiole, is that however irregularly they may be lobed, they are almost invariably primarily bilobed.

Though so restricted a genus now, its ancestry is perhaps more venerable than that of any other forest tree. The Carboniferous fruits Trigonocarpus and Noeggerathia are believed by both Hooker and Saporta to have belonged to some ancestral form, and even the foliage of the latter, Psygmophyllum of Schimper, approaches nearly to that of Ginkgo. Baieria, beyond doubt a close ally, appears in the Permian, and Ginkgo in all probability in the bilobate Jeanpaulia of the Rhœtic of Bayreuth, but the group did not reach its maximum until the Jurassics. A few species have been described in other works, but Heer's Jurassic flora of Eastern Siberia ("Flora foss. Arctica," vol. iv.) contains by far the most important contribution to their past history. Five genera are placed in the groups: Phonicopsis, Ginkgo, Baieria, Trichopitys, and Czekanowskia, but there is no.special character uniting the latter to Ginkgo, although it is no doubt coniferous. The remains are clusters of occasionally forked acicular leaves, sheathing at the base in imbricated scales. The leaves widen in most specimens here and there into bead-like expansions, inferred to have been caused by some extinct type of parasitic fungus. It is thought by Heer that a detached stem bearing shortly petiolated double seeds or nuts may be their fruit. Phœnicopsis is a cluster of separate leaves, also sheathing in scales at the base, but forming a fine palm-like foliage, thought by Heer to unite Cordaites and Baieria, yet without any direct affinity with Ginkgo.

The most aberrant of the genera obviously belonging to the group is Trichopitys of Saporta. In this the leaves were smaller, with fewer veins, and the parenchyma reduced to a narrow expansion margining each vein. Although so extreme a modification of the normal type, $T$. setacea $^{1}$ possesses the characteristic bilobation and petiole. Its affinity is best traced through $G$. concinna, which is similar, but with the segments of the leaves expanded to receive two to three veins each.

$G$. sibirica and $G$. lepida are separated on trivial grounds not supported by the illustrations, and when united furnish the chief and most abundant leaves in the deposit. These are nearly as large as in the existing species, but more digitate, and with about five veins to ${ }^{1} T$. passilla probably belongs to some other division of the vegetable kingdom. 
each segment. They have the venation, bilobation, and petiole of Ginkgo, yet approaching in their larger leaves to Baieria. Other similar species (?) diminishing in size are $G$. schmidtiana, with about six segments, $G$. flabellata, with fourteen or fifteen segments, and $G$.pusilla, with a less number, and barely an inch across the base. These three might probably be united into a single species. The remaining form from Siberia, G. huttoni, is less divided, having but four rounded segments, and is in that respect a nearer approach to the existing one.

The nearest, however, is $G$. digitata from the Jurassic of Spitzbergen, which, but for smaller size and thicker petiole, might be placed in the existing species. Leaves from Scarborough, said to be of the same species, are larger. $G$. integriuscula is evidently the smaller and less lobate leaf of the same species, and the author has besides taken the unnecessary care to establish five duly named and lettered varieties, thus clearly showing that he had formed no adequate conception of the extent to which the leaves of the existing tree may vary, even on the same branch. His species should be reduced, the excessive srbdivision being a disadvantage and rendering the work unwieldy. The author also changes the-classification of the Coniferæ between the-second and third volumes, and the name for this genus between the third and fourth volumes, without explanation or notice, which, in a work addressed especially to geologists, is an inconvenience.

The third genus, Baieria, posiesses a larger and more palm like leaf, averaging nearly five inches in radius, primarily bilobed, each lobe forking either once or twice, the ultimate segments being of uniform width and possessing four parallel veins each. The leaf tapers to the petiole, which is not preserved in the engraved specimens. The bilobation and venation connect it sufficiently with Ginkgo, and the persistence of these characters throughout the whole group, which would hardly have been suspected to have a morphologic value, is peculiarly remarkable.

There is a marked diminution in the group in the Cretaceous. Baieria from the Komeschichter is limited to vestiges of stunted form placed among the ferns, while Ginkgo appears in a starved species with small leaves and short thick petiole, described as Adizntum for. mosum, and by fragments from the Upper Cretaceous Ataneschichten, inappropriately named $G$. primordialis.

In the Arctic Eocenes (Miocenes of Heer) Ginkgo has only, and that very sparingly, been met with in Greenland. This variety so resembled $G$, adiantoides of the Ifalian Miocenes, that Heer almost directly abandoned his spocific name primordialis, and became doubtful eren whether both should not be united with the existing speeies.

The small fragments frgured in the Miocene Baltic flora are inconclusive, and we only again meet with it in the Miocenes as far south as Italy, the South of France, and the Mississippi. ${ }^{1}$ It has been said to occur in English Eocenes by Heer, who wrote upon the tracing of an Adiantum from Bournemouth, "this is a Ginkgo," and by Ettingshausen, who considers four seeds from Sheppey to belong to it, although less than half the size of those of the present Ginkgo, and rather materially differing. Ifs absence otherwise in British and in French Eocenes, and in the Swiss and Austrian Tertiaries, is ascertained, for the occurrence of so distinctly-marked and easilypreserved a leaf could not well be overlooked.

The very strongly-marked and exceptional characters of Ginkgo, shared by the allied extinct genera, the remoteness of its origin in the Carboniferous, its extensive development in the Mesozoic, and persistence through so many ages, seems to render it desirable to separate them from the Taxeæ into a distinct tribe. Already dying out in the Cretaceous and lingering through the Tertiaries in a single species, its existence now is a mere survival.

${ }^{x}$ Since writing the abcve, Saporta infurms me that the supposed Mississippi species is really a Lygodium.
Its ho:ne has been from time to time within the Arctic circle, yet it is scarcely proved, as Saporta says, that it actually originated there. The leaf of $G$. digitata from the Scarborough oolite, figured by Schimper, is far larger than any fizured from Spitzbergen, and neither the foliage nor the fruit of the northern fossil Ginkgo, it appears, ever at any time approached those of the existing tree in its native habitats. It is now indigenous to the northern provinces of China, and must therefore be capable of withstanding a rigorous climate; yet the conditions in Western Europe do not appear to favour the ripening of its seed in hisher latitudes than the South of France.

Its distribution during the Tertiaries is instructive, and Saporta's explanation, that it existed in the north during the warm Eocene and pre-Eocene times, and descended thence across Europe as the temperature decreased, on the approach of the Miocene time, is the only one that explains the facts. To suppose with Heer that the same species lived contemporaneously and at the same level in Italy and in Disco is absurd, and would presuppose a uniformity of climate such as no natural causes could have produced at so recent a geological period.

J. STARKIE GARDNER

\section{NOTES}

THE Roman Academy of Sciences has awarded half of the King Humbert Prize, now awarded for the first time, to the German astronomer, Dr. Wilhelm Tempel, director of the Acetri Observatory at Florence, for his observations on nebulx.

DEATH is levying heavy contributions from the students of entomolcgy in France, more especially as regards the oldest and best known. We very recently had occasion to notice the decease of Etienne Mulsant, at a ripe age. Now, we regret to have to anmounce the death of Achille Guenée of Châteaudun, whose name is probably more known in England than is that of any other French entomologist. He died on the 3 oth ult. (his colleague and fellow-worker, Dr. Boisduval, died on December 30 , 1879), in his seventy-second year. Guenée was a lepidopterist. His publications are very numerous. The most important of all are the six volumes of the series termed the "Suites à Buffon" on some of the principal families of the Lepidoptera of the world, which appeare 1 from 1852 to 1857 . These volumes formed a basis for future students of Lepidoptera, and largely influenced those of them amongst our own countrymen. The town of Châteaudun occupies a not unimportant position in the history of the Franco-Prussian war. Guené:'s house was occupied by the Prussian troops. He himself took refuge in Geneva, and, true to his predilections, studied the Lepidoptera in the collection of the museum of that city; the results of his investigations were published. We believe that when circum. stances permitted his return, his own collections were found to have suffered very little damage at the hands of his unbidden guests. He was an officer of the French Academy. Our Entomological Society of London elected him one of its honorary members many years ago; and his friends amongst Englishmen were not few.

John DUNCAN, a poor Aberdeenshire weaver, has presented to the University of Aberdeen his herbarium of nearly 1200 British plants, gathered by him all over the country from Northumberland to Banff, while acting as a harvest labourer. The story of Duncan was told in Good Words for 1878 , by Mr. William Jolly, and now it would seem that the poor and intelligent werver is so reduced in circumstances as to be compelled to accept parochial relief. Surely the University of Aberdeen ought to do something for him; and possibly some of our readers may care to send a trifle to John Dumcan, Droughsburn, by Alford, Aberdeenshire. 